\title{
Formulation and Evaluation of Orodispersible Tablets of Apremilast by Inclusion Complexation using $\beta$-Cyclodextrin
}

\author{
Darshana Pravinchandra Panhale ${ }^{1, *}$, Rishikesh Shankar Bachhav², Sheetal Bhaskar Gondkar ${ }^{3}$ \\ 1Department of Pharmaceutical Quality Assurance, R.G. Sapkal College of Pharmacy, Anjaneri, Nashik, Maharashtra, INDIA. \\ ${ }^{2}$ Department of Pharmacology, R.G. Sapkal College of Pharmacy, Anjaneri, Nashik, Maharashtra, INDIA. \\ ${ }^{3}$ Department of Pharmaceutics, R.G. Sapkal College of Pharmacy, Anjaneri, Nashik, Maharashtra, INDIA.
}

\begin{abstract}
Introduction: The present study was carried out to formulate and evaluate orodispersible tablets of Apremilast with a purpose of providing better patient compliance to geriatric, pediatric, impaired, travelling and non-cooperative patients suffering from psoriasis. Such patients are in need of fast and easy swallowing drug delivery system. Materials and Methods: The Apremilast- $\beta$-cyclodextrin inclusion complex was prepared by physical blending method with a principle of increasing the solubility and permeability of drug. The inclusion efficiency of Apremilast: $\beta$-cyclodextrin ratios $(1: 1,1: 2,1: 3)$ were calculated and it was investigated that $1: 2$ ratio complex is highest. The orodispersible tablets of apremilast ( $F 1$ to $F 9$ ) were prepared by simple and cost effective direct compression technique using different concentrations of super disintegrate croscarmellose sodium. Results: The results of pre-compression characteristics of powder blends and postcompression parameters of tablets were studied and showed satisfactory. Among all formulations studied, Formulation F6 showed less disintegration time and percent cumulative drug release $98.7 \%$ so it was declared as an optimized formulation. Conclusion: Therefore, It can be concluded that drug dissolution, absorption, therapeutic effect and bioavailability can be significantly greater than those as compared with conventional treatment of psoriasis in a cost-effective manner with better patient compliance.
\end{abstract}

Key words: Psoriasis, Orodispersible Tablet, Inclusion Complexation, Apremilast- $\beta$ cyclodextrin, Croscarmellose sodium.

\section{INTRODUCTION}

Tablet is the most convenient among all drug delivery systems because of its convenience of self-administration, compactness and easy manufacturing. However dysphasia or difficulty in swallowing in case of geriatric patients, pediatric, travelling patients who may not have ready access to water, uncooperative patients are common phenomenon's which leads to poor patient compliance. ${ }^{1}$ To overcome these disadvantages, Orodispersible tablets has emerged as alternative oral dosage forms.

Orodispersible tablets are also called as orally disintegrating tablets (ODTs), mouthdissolving tablets (MDTs), rapid-dissolving tablets, fast-disintegrating tablets, fastdissolving tablets (FDTs), porous tablets and rapimelts. European Pharmacopoeia seventh edition and United States Pharmacopoeia (USP) has used the term orodispersible tablets and defined as uncoated tablets intended to be placed in the mouth where they disperse or disintegrate readily within $3 \mathrm{~min}$ before swallowing. Orodispersible tablets are solid unit drug delivery system composed of super disintegrates, which disintegrate or disperse the tablets within $3 \mathrm{~min}$ in the presence of saliva in mouth without any difficulty of swallowing. ${ }^{2}$ It has numerous advantages with respect to its administration
Submission Date: 22-04-2020; Revision Date: 14-08-2020; Accepted Date: 23-10-2020

DOI: 10.5530/ijper.55.1s.42 Correspondence:

Ms. Darshana Panhale

Department of Pharmaceutical Quality Assurance,

RG Sapkal College of

Pharmacy, Anjaneri, Nashik, Maharashtra, INDIA.

Phone no: +919665462606 Email id:

darshanapanhale24@gmail. com

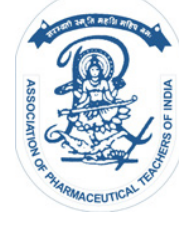

www.ijper.org 
without water, accurate dosing, easy manufacturing, small packaging size, stability and handling. Its ease of administration in the population especially for pediatric, geriatric, or any mentally retarded persons makes orodispersible tablets a very popular drug delivery system. Due to the presence of super disintegrates, it gets dissolved quickly, resulting in rapid absorption of drug which in turn provides rapid onset of action. Since the absorption is taking place directly from the mouth, so, bioavailability of the drug increases. Drugs present in orodispersible tablets are also not suffering from first pass metabolism. This type of drug delivery is becoming popular day by day due to its several advantages. ${ }^{3}$

The present invention relates to the development of orodispersible tablets of Apremilast by inclusion complexation Using $\beta$-Cyclodextrin. Apremilast is a PDE-4 (Phosphodiesterase 4) inhibitors, an orally administered small molecule, which has shown great promise in treating patients with psoriasis, few other dermatologic disorders and certain type of arthritis (psoriatic arthritis). Apremilast decreases pain and swelling in patients those are suffering from psoriatic arthritis and help to improve flexibility in the affected joints. It help to reduce the redness, thickening and scaling of the skin in the treatment of plaque psoriasis. In this way apremilast plays a noteworthy anti-inflammatory and anti-psoriatic role. ${ }^{4}$

Being BCS class-4 Drug, Apremilast has low solubility and low permeability. Many attempts or means have been used to increase the solubility and permeability of Apremilast. It can be increased by forming a complex with $\beta$-Cyclodextrin. $\beta$-Cyclodextrin enhances the aqueous solubility of drugs and hence permeability through inclusion complexation (Table 1) which will be used to formulate orodispersible tablets. This will not only enhance the bioavailability of the drug but also reduce the onset of action due to fast absorption of drug from GIT as drug will be available as ready to absorption i.e. in solution form from the mouth cavity itself. ${ }^{5}$

\section{MATERIALS AND METHODS}

\section{Materials}

Apremilast was provided for the study by Glenmark Pharmaceuticals Ltd., (Pune, India). $\beta$-cyclodextrin, mannitol, Croscarmellose sodium and magnesium stearate were obtained from Research Lab Fine Chem Industries (Mumbai, India). Apremilast tablets (Aprezo, Glenmark, the reference tablet) were purchased. All other chemicals and reagents used were of analytical grade.

\section{Methods}

\section{Preparation of Apremilast- $\beta$-cyclodextrin complexby} Physical blending method

Complex can be prepared using $\beta$-cyclodextrin. In the present study one carrier was used. The complex was made by Physical blending method (Table 2). The required molar $(1: 1,1: 2,1: 3)$ quantities of the Drug: $\beta$-cyclodextrin were weighed accurately and blended together thoroughly in a mortar at laboratory scale, with vigorous trituration, for about $30 \mathrm{~min}$. These mixtures then passed through sieve no 44 and finally stored in airtight containers till further use. The physical mixtures were also prepared at large scale by blending Apremilast with $\beta$-CD in a rapid mass granulator for 30 mins. These powdered physical mixtures were then stored in the room at controlled temperature $\left(25^{\circ} \pm 2.0^{\circ}\right)$ and humidity conditions (Relative humidity $40-50 \%$ ) for comparison with the corresponding solid complex powders. ${ }^{6}$

\section{Evaluation of complex Production Yield}

The production yield of complex's of various combinations was calculated using the weight of final product after drying with respect to the initial total weight of the drug and carrier used for the preparation of complex. Percent production yields were calculated as per the formula mentioned below,

$$
\mathrm{P}_{\mathrm{Y}}=\frac{\mathrm{W}_{\mathrm{O}}}{\mathrm{W}_{\mathrm{T}}} \times 100
$$

Where,

$\mathrm{P}_{\mathrm{Y}}=$ Product yield,

$\mathrm{W}_{\mathrm{O}}=$ Practical mass (complexs)

$\mathrm{W}_{\mathrm{T}}=$ Theoretical mass (carrier + drug)

\section{Drug Content (Inclusion efficiency)}

About $10 \mathrm{mg}$ drug equivalent of complexes (theoretical) were weighed accurately and transferred to $100 \mathrm{ml}$ volumetric flask. From this stock solution $(100 \mu \mathrm{g} /$ $\mathrm{ml}), 1 \mathrm{ml}$ was withdrawn and further diluted up to 10 $\mathrm{ml}$ with methanol. This solution was used for the assay for drug content by UV spectrophotometer at $230 \mathrm{~nm}$. Concentration of drug in stock solution was calculated by using calibration curve and from which percent drug content in complex was calculated.

$$
\% \text { Drug Content }=\frac{\mathrm{W}_{\mathrm{A}}}{\mathrm{W}_{\mathrm{T}}} \times 100
$$

Where,

$\mathrm{W}_{\mathrm{A}}=$ Actual drug content,

$\mathrm{W}_{\mathrm{T}}=$ Theoretical drug content. 
Table 1: Enhancement of Absorption of BCS Class 4 Drug.

\begin{tabular}{|c|c|c|c|c|}
\hline BCS Class & Solubility & Permeability & Rate Determining Step to drug absorption & Effect of Cyclodextrin Complication \\
\hline 1 & High & High & Good Bioavailability & Can decrease absorption \\
\hline 2 & Low & High & Aqueous diffusion & Can enhance absorption \\
\hline 3 & High & Low & Membrane Permeation & Can decrease absorption \\
\hline 4 & Low & Low & Aqueous diffusion and Membrane Permeation & Can enhance absorption \\
\hline
\end{tabular}

BCS stands for Biopharmaceutical Classification System.

Table 2: Different ratios used for preparation of complex.

\begin{tabular}{|r|c|c|c|c|}
\hline $\begin{array}{r}\text { Sr. } \\
\text { No. }\end{array}$ & Carrier & \multicolumn{3}{|c|}{$\begin{array}{r}\text { Drug(Apremilast): Carrier } \\
\text { ( } \mathbf{\beta} \text {-Cyclodextrin) Ratio (w/w) }\end{array}$} \\
\hline 1. & $\beta$-Cyclodextrin & $1: 1$ & $1: 2$ & $1: 3$ \\
\hline
\end{tabular}

\section{Saturation Solubility Study}

Saturation solubility studies was carried out for complex prepared. This study was the basic criteria to identify and judge a complex of choice, which would enhance the solubility and so, would show good results in in-vitro dissolution studies. The following procedure remains same for the drug and their complex. Solubility studies were carried out in glass vials. In each of these vials, $10 \mathrm{ml}$ distilled water was added. Excess quantities of complexes were added into each of vials. These vials were shaken continuously for $24 \mathrm{hr}$ on a lab shaker and the resulting solutions were filtered, appropriate dilutions were made and UV absorbance's were recorded at $230 \mathrm{~nm}$.

\section{Dissolution Studies of Complex}

The in vitro dissolution studies for complex were carried in USP Apparatus 2. Samples equivalent to $10 \mathrm{mg}$ of Apremilast were added to $900 \mathrm{~mL}$ of phosphate buffer $\mathrm{pH} 6.8$ at $37 \pm 0.5^{\circ} \mathrm{C}$ and stirred at $50 \mathrm{rpm}$. $10 \mathrm{ml}$ aliquots were withdrawn at time intervals of 5, 10, 15, 20, 25, 30, 45, $60 \mathrm{~min}$. and filtered through Whatman No. 41 filter paper. An equal volume of fresh dissolution medium was replaced to maintain the volume of dissolution medium. The filtered samples were analysed spectrophotometrically at $230 \mathrm{~nm}$. Cumulative percentage of labelled amount of drug released was calculated. ${ }^{7}$

\section{Method of Preparation of Powder Blend}

Complex of Apremilast: $\beta$-cyclodextrin (containing appropriate amount of complex which is equivalent to $10 \mathrm{mg}$ of apremilast) and other inactive ingredients along with varying $\%$ of Croscarmellose sodium at three concentration levels. Formulations coded as F1 to F9 respectively. In the first step, active and inactive ingredients weighed accurately and were screened through a 60-mesh sieve. The complex (Apremilast: $\beta$-cyclodextrin) and superdisintegrant Croscarmellose sodium were blended first in mortar and pestle then the remaining ingredients are added in that and blended for 20 min. Finally the blend is passed through mesh \#40 and used for evaluation of flow characteristic. ${ }^{8}$ Formula for Orodispersible tablet of apremilast is shown in Table 3.

\section{Evaluations of powder blend for flow properties}

\section{Bulk Density}

An accurately weighed powder blend from each formula was lightly shaken to break any agglomerates formed and it was introduced in to a measuring cylinder. The volume occupied by the powder was measured which gave bulk volume. Bulk density of powder blends was determined using the following formula.

$$
\text { Bulk density }=\frac{\text { Total weight of powder }}{\text { Total volume of powder }}
$$

\section{Tapped density}

An accurately weighed powder blend from each formula was lightly shaken to break any agglomerates formed and it was introduced into a measuring cylinder. The measuring cylinder was tapped until no further change in volume was noted which gave the tapped volume. The tapped densities (TD) of powder blends were determined using the following formula. ${ }^{?}$

Tapped bulk density $=\frac{\text { Total weight of powder }}{\text { Total volume of tapped powder }}$

\section{Angle of Repose}

Angle of repose has been used to characterize the flow properties of solids. It is a characteristic related to inter particulate friction or resistance to movement between particles. The angle of repose $(\theta)$ for powder was determined by placing the powder in a funnel. The tip of the orifice of the funnel was fixed from the ground horizontal surface at a height of $1 \mathrm{~cm}$ and the powder were allowed to flow only under the force of gravity. The angle of repose, $\theta$ was calculated from the following relationship. 


\begin{tabular}{|c|c|c|c|c|c|c|c|c|c|c|}
\hline \multirow{2}{*}{$\begin{array}{l}\text { Sr. } \\
\text { No. }\end{array}$} & \multirow{2}{*}{$\begin{array}{l}\text { Ingredients } \\
\text { (mg) }\end{array}$} & \multicolumn{9}{|c|}{ Formulations } \\
\hline & & $F_{1}$ & $F_{2}$ & $F_{3}$ & $F_{4}$ & $F_{5}$ & $\mathbf{F}_{6}$ & $F_{7}$ & $F_{8}$ & $F_{9}$ \\
\hline 1. & Apremilast & 10 & 10 & 10 & 10 & 110 & 10 & 10 & 10 & 10 \\
\hline 2. & $\beta$-cyclodextrin & 15 & 15 & 15 & 20 & 20 & 20 & 25 & 25 & 25 \\
\hline 3. & Croscarmellose Sodium & 1 & 3 & 5 & 1 & 3 & 5 & 1 & 3 & 5 \\
\hline 4. & Mannitol & 72 & 70 & 68 & 67 & 65 & 63 & 62 & 60 & 58 \\
\hline 5. & Magnesium stearate & 2 & 2 & 2 & 2 & 2 & 2 & 2 & 2 & 2 \\
\hline \multirow[t]{2}{*}{6.} & Orange Flavour & q.s & q.s & q.s & q.s & q.s & q.s & q.s & q.s & q.s \\
\hline & Total $(\mathrm{mg})$ & 100 & 100 & 100 & 100 & 100 & 100 & 100 & 100 & 100 \\
\hline
\end{tabular}

$$
\tan \theta=\mathrm{h} / \mathrm{r}
$$

Where, $b$ is height of the pile of powder $(b=1)$ and $r$ is the radius of the base of cone.

\section{Hausner Ratio}

Hausner's ratio was determined by following equation, Hausner's Ratio=Tapped bulk density/Loose bulk density. A hausner ratio less than 1.12 indicates good flow while greater than 1.35 indicate poor flow.

\section{Compressibility Index}

It is a simple index that can be determined on small quantities of powder. In theory, the less compressible a material the more flow able it is. ${ }^{10}$ The compressibility indices of the powder blends was determined using following formula,

$$
\text { Carr's Compressibility Index }(\%)=\frac{[(\text { Tapped Bulk Density }-}{\text { Loose Bulk Density })} \underset{\text { Tapped Bulk Density }]}{ } \times 100
$$

\section{Preparation of Apremilast Orodispersible tablets using the direct compression technique}

After evaluation of powder blend the Orodispersible tablets were prepared by direct compression method using tablets using 10-station rotary tablet compression machine (karnavati) equipped with flat-faced $6 \mathrm{~mm}$ punches before compression, the surfaces of the die and punch were lubricated with magnesium stearate. Nine types of formulations containing variable amount of superdisintegrant were prepared. All the preparations were stored in airtight containers at room temperature for further study. ${ }^{11}$

\section{Evaluation of Orodispersible Tablet of Apremilast Thickness}

The thickness of tablet is important for uniformity of tablet size. The thickness of the tablets was determined using a Vernier Calliper. Three tablets from each batch were used.

\section{Hardness}

For each formulation, the hardness of three tablets was checked using the Monsanto hardness tester.

\section{Drug Content Uniformity Study}

Five tablets were weighed individually and powdered. The powder equivalent to $10 \mathrm{mg}$ of Apremilast was weighed and dissolved in methanol. The volume was made to $100 \mathrm{ml}$ with methanol. From this stock solution, $10 \mu \mathrm{g} / \mathrm{ml}$ dilution was prepared. The drug contents of the resulting solution were calculated from UV absorbance at $230 \mathrm{~nm}^{12}$

\section{Friability}

Friability is the measure of tablet strength. In this test number of tablets subjected to combined effect of shock abrasion by utilising a plastic chamber which revolves at a speed of $25 \mathrm{rpm}$, dropping the tablets at a distance of 6 inches in each revolution. A sample of preweighed tablets was placed in Roche Friability tester (Kumar Mfg. Ltd.) This was then operated for 100 revolutions. The tablets then dedusted and reweighed. Permitted friability limit is $1.0 \%$. Tablets were then weighed and friability values were determined.

$$
\text { Friability }=\frac{\mathrm{W}_{1}-\mathrm{W}_{2}}{\mathrm{~W}_{1}} \times 100
$$

Where,

$\mathrm{W}_{1}$ = weight of the tablets before test,

W2 = weight of the tablets after test

\section{Weight Variation Test}

Twenty tablets were weighed individually. Average weight was calculated from the total weight of all tablets. The individual weights were compared with the average weight. The percentage difference in the weight variation should be within the acceptable limits 
$( \pm 7.5 \%)$. The percent deviation was calculated using the following formula.

$$
\% \text { Deviation }=\frac{\begin{array}{l}
\text { Individual weight }- \\
\text { Average weight }
\end{array}}{\text { Average weight }} \times 100
$$

\section{Wetting Time}

A piece of tissue paper folded double was placed in a petri dish containing $6 \mathrm{ml}$ of water. The tablet was placed on the paper and the time for complete wetting of the tablet was measured in seconds. The method was slightly modified by maintaining water at $37^{\circ} \mathrm{C}$. Wetting time corresponding to the time taken for the tablet to disintegrate when kept motionless on the tongue was calculated. ${ }^{13}$

\section{Water Absorption Ratio}

The water absorption ratio is used to determine the amount of water absorbed by the tablet. A piece of tissue paper folded twice was placed in small Petri dish $(7.5 \mathrm{~cm})$ containing $7 \mathrm{ml}$ water. A tablet was put on the tissue paper and allows wetting completely. The wetted tablet was then weighed. The water absorption ratio $R$ was determined using following equation.

$$
\mathrm{R}=\frac{\mathrm{W}_{\mathrm{a}}-\mathrm{W}_{\mathrm{b}}}{\mathrm{W}_{\mathrm{a}}} \times 100
$$

Where;

$\mathrm{W}_{\mathrm{a}}=$ weight of a tablet after absorption

$\mathrm{W}_{\mathrm{b}}^{\mathrm{a}}=$ weight of a tablet before absorption

\section{Disintegration Time}

The in-vitro disintegration studies were carried out using Tablet Disintegration Test Apparatus. One tablet was placed in each of the six tubes of the basket assembly and disk was added to each tube. This assembly was then suspended in one-liter beaker containing distilled water maintained at $37 \pm 2^{\circ} \mathrm{C}$. The basket was then moved up and down through a distance of 5 to $6 \mathrm{~cm}$ at a frequency of 28 to 32 cycles per minutes. The time required for complete disintegration of the tablet was recorded. The test was performed for tablets of all type of formulation (F1-F9).

\section{In- vitro Drug Release Study}

An in-vitro drug release studies of the prepared nine formulations of Orodispersible Tablets were conducted for a period of $15 \mathrm{~min}$ using an eight station USP type 2 apparatus (paddle type). The agitation speed was $50 \mathrm{rpm}$. Apremilast tablets were added to $900 \mathrm{ml}$ of phosphate buffer $\mathrm{pH} 6.8$ at $37 \pm 0.5^{\circ} \mathrm{C} .5 \mathrm{ml}$ aliquots were withdrawn at time intervals of $1,3,5,7,9,11,13,15 \mathrm{~min}$. and filtered through Whatman No. 41 filter paper. An equal volume of fresh dissolution medium was replaced to maintain the volume of dissolution medium. The filtered samples were analysed spectrophotometrically at $230 \mathrm{~nm}$. Cumulative percentage of labelled amount of drug released was calculated. ${ }^{14}$

\section{Stability Studies}

The optimized formulation was wrapped in aluminum foil and subjected to $40 \pm 2^{\circ} \mathrm{C}$ temperature and $75 \pm 5 \% \mathrm{RH}$ in oven for the period of Three months. The formulation was analyzed for organoleptic characteristics, Thickness, hardness, drug content, wetting time, Disintegration time, weight variation and dissolution. In any rational design and evaluation of dosage forms for drugs, the stability of the active component is the major criteria in determining their acceptance or rejection. Stability studies were carried out as per $\mathrm{ICH} \mathrm{Q}_{1} \mathrm{~A}$ guidelines. During the stability studies, the product is exposed to normal conditions of temperature and humidity. The optimized Apremilast formulations were subjected for stability studies.

Packaging material: The tablets were wrapped in aluminum foils.

Sampling points: The optimized formulations were subjected to stability for a period of Three months. The samples were withdrawn at the end of three months. ${ }^{15}$

\section{RESULTS AND DISCUSSION}

\section{Preparation of Apremilast- $\beta$-cyclodextrin complex}

Complexes were prepared using $\beta$-Cyclodextrins with the principle of increasing the solubility and permeability of drug. Drug: Carrier ratios were decided arbitrarily $(1: 1,1: 2,1: 3)$ based on the literature review and success achieved with a range of ratios for any carrier. Complex was made by Physical blending method. ${ }^{16}$

\section{Evaluation of Complex}

\section{Production Yield}

The production yield of all Drug: Carrier ratios by physical blending method was found to be in the range of 98 to $99 \%$. Any loss in yield can be attributed to the product remaining adhered to the walls of the evaporating dish or the mortar which could not be retrieved.

\section{Drug content (Inclusion efficiency)}

The drug content of different ratios was calculated and found to be in range of 95 to $98 \%$.The $\%$ drug content 


\begin{tabular}{|c|c|c|c|}
\hline \multicolumn{3}{|c|}{ Table 4: Saturation solubility data for apremilast and } \\
carrier combinations. \\
$\begin{array}{c}\text { Sr. } \\
\text { no }\end{array}$ & $\begin{array}{c}\text { Apremilast: carrier } \\
\text { combination }\end{array}$ & $\begin{array}{c}\text { Saturated } \\
\text { Solubility } \\
(\boldsymbol{\mu g} / \mathrm{ml})\end{array}$ & $\begin{array}{c}\text { Drug } \\
\text { content (\%) }\end{array}$ \\
\hline 1. & Apremilast: $\beta-\mathrm{CD}(\mathrm{PM} \mathrm{1:1)}$ & 5.8446 & $95.68 \pm 0.76$ \\
\hline 2. & Apremilast: $\beta-\mathrm{CD}(\mathrm{PM} \mathrm{1:2)}$ & 12.7840 & $98.80 \pm 0.44$ \\
\hline 3. & Apremilast: $\beta-\mathrm{CD}(\mathrm{PM} \mathrm{1:3)}$ & 9.6401 & $96.53 \pm 0.56$ \\
\hline
\end{tabular}

$C D$ is Cyclodextrin and PM stands for Physical blending Method.

of 1:2 ratio complex is highest (Table 4) and hence found satisfactorily.

\section{Saturation solubility study}

The effect on solubility of Apremilast after preparation of their complex using physical blending methods, saturation solubility studies were performed in distilled water. The results for saturation solubility of apremilast was shown in Table 4. It was studied that an increase in solubility of about 2.4 -fold with $\beta$-Cyclodextrins (1:2 PM) was achieved when compared to the solubility of APM:CD (1:1). Correlating the solubility data with the concentration of carrier with respect to drug, it was observed that the solubility increased with increasing concentration of the carrier Upto 1:2. Based on the literature review, the most common ratio of drug/ $\beta$-cyclodextrin complexes is the 1:2 where the 1:2 complex is formed when one additional $\beta$-cyclodextrin molecule forms a complex with an existing 1:1 complex. Hence, saturation solubility of different ratios was calculated, that shows 1:2 complex is highest. ${ }^{17}$

\section{Dissolution studies of complex}

The in-vitro profiles of the drug and complexes are shown in Table 5 . Standard deviation up to $5 \%$ is allowed. The drug exhibited a slow dissolution, suggesting that its absorption in vivo would be dissolution rate limited, whereas complexes showed a marked enhancement in dissolution rate. Thus, dissolution up to $101.48 \%$ for 1:2 complex was recorded in $10 \mathrm{~min}$ contrast to 47.53 $\%$ drug release within 10 min observed from marketed preparation of drug (Aprezo, the reference tablet, Glenmark). Further, the dissolution profile of complexes with different mixing ratios also demonstrated variability and it was found to be dependent on the drug-carrier ratio. Hence, from all the ratios used, maximum dissolution was investigated for Apremilast: $\beta$-cyclodextrin 1:2. ${ }^{18}$

\section{Evaluation of powder blend}

Evaluation of powder blend Containing Apremilast- $\beta$ Cyclodextrin Complexare Table 6.

\begin{tabular}{|c|c|c|c|c|}
\multicolumn{5}{|c|}{ Table 5: Results of dissolution studies of complexes } \\
of apremilast. \\
\hline $\begin{array}{c}\text { Time } \\
\text { (Min.) }\end{array}$ & (\%) Drug Release \\
\cline { 2 - 5 } & Drug & $1: 1$ & $1: 2$ & $1: 3$ \\
\hline 1 & $21.39 \pm 0.74$ & $22.45 \pm 0.45$ & $66.45 \pm 0.65$ & $32.46 \pm 0.23$ \\
\hline 5 & $26.39 \pm 0.67$ & $22.88 \pm 0.89$ & $97.73 \pm 0.56$ & $32.88 \pm 0.44$ \\
\hline 10 & $47.53 \pm 0.65$ & $31.25 \pm 0.65$ & $101.48 \pm 0.46$ & $42.18 \pm 0.67$ \\
\hline 15 & $56.85 \pm 0.66$ & $46.85 \pm 0.32$ & $93.94 \pm 0.23$ & $50.55 \pm 0.34$ \\
\hline 30 & $62.35 \pm 0.23$ & $51.34 \pm 0.46$ & $83.64 \pm 0.66$ & $56.35 \pm 0.23$ \\
\hline 45 & $65.34 \pm 0.45$ & $64.18 \pm 0.42$ & $67.79 \pm 0.59$ & $70.68 \pm 0.43$ \\
\hline 60 & $69.10 \pm 0.64$ & $65.05 \pm 0.98$ & $52.90 \pm 0.96$ & $73.71 \pm 0.87$ \\
\hline
\end{tabular}

Data expressed are average of triplicate $(n=3 \pm S D)$

\section{Bulk Density}

The powder blends of formulations have the bulk density ranged between 0.4564 to $0.5674 \mathrm{gm} / \mathrm{ml}$.

\section{Tapped density}

The powder blends of formulations have the tapped bulk density ranged between 0.5123 to $0.6578 \mathrm{gm} / \mathrm{ml}$.

\section{Angle of repose}

The flow properties of blend were analyzed by determining angle of repose which was found to be between 25-30 indicating good flow property.

\section{Hausner's Ratio}

The hausner ratio for the formulations was found to be $<1.00-1.11$, indicating excellent flow properties and 1.12-1.18 indicating good flow property.

\section{Carr's Compressibility Index}

The Carr's index for the formulations was found to be below $<10 \%$ indicating that the powders have a excellent compressibility and 11-15 indicating good compressibility. ${ }^{19}$

\section{Formulation of Orodispersible tablet by direct compression technique}

The present investigation was undertaken to formulate and evaluate orodispersible tablets of apremilast- $\beta$-CD complex by direct compression method. Nine different formulations (F1 to F9) were prepared by using various concentrations of super disintegrant Croscarmellose sodium to assist fast disintegration. ${ }^{20}$

\section{Evaluation of Tablets}

All batches of prepared tablets were evaluated for the different parameters and are shown in Table 7 and Table 8. 


\begin{tabular}{|c|c|c|c|c|c|}
\hline \multirow{2}{*}{$\begin{array}{c}\text { Formulation } \\
\text { Batches }\end{array}$} & \multicolumn{5}{|c|}{ Physical properties } \\
\hline & $\begin{array}{l}\text { Bulk density } \\
\text { (gm/ml) }\end{array}$ & $\begin{array}{l}\text { Tapped density } \\
(\mathrm{gm} / \mathrm{ml})\end{array}$ & $\begin{array}{l}\text { Angle of repose } \\
\left({ }^{\circ} \mathrm{C}\right)\end{array}$ & $\begin{array}{l}\text { Compressibility } \\
\text { Index (\%) }\end{array}$ & Hausner Ratio \\
\hline $\mathrm{F} 1$ & $0.4761 \pm 0.05$ & $0.5263 \pm 0.06$ & $27.09 \pm 0.98$ & $12.3 \pm 0.68$ & $1.12 \pm 0.07$ \\
\hline $\mathrm{F} 2$ & $0.4657 \pm 0.03$ & $0.6578 \pm 0.09$ & $28.05 \pm 0.86$ & $11.45 \pm 0.76$ & $1.06 \pm 0.06$ \\
\hline F3 & $0.4856 \pm 0.08$ & $0.5345 \pm 0.07$ & $29.76 \pm 0.52$ & $13.45 \pm 0.94$ & $1.12 \pm 0.07$ \\
\hline $\mathrm{F} 4$ & $0.5634 \pm 0.06$ & $0.5643 \pm 0.06$ & $27.57 \pm 0.86$ & $21.45 \pm 0.46$ & $1.25 \pm 0.05$ \\
\hline F5 & $0.5674 \pm 0.07$ & $0.5123 \pm 0.03$ & $28.35 \pm 0.55$ & $15.5 \pm 0.98$ & $1.17 \pm 0.02$ \\
\hline F6 & $0.4658 \pm 0.04$ & $0.5263 \pm 0.09$ & $26.09 \pm 0.97$ & $9.52 \pm 0.67$ & $1.10 \pm 0.09$ \\
\hline F7 & $0.5378 \pm 0.07$ & $0.5134 \pm 0.08$ & $28.79 \pm 0.45$ & $9.35 \pm 0.65$ & $1.19 \pm 0.07$ \\
\hline F8 & $0.4978 \pm 0.03$ & $0.5867 \pm 0.05$ & $29.34 \pm 0.73$ & $13.5 \pm 0.89$ & $1.16 \pm 0.05$ \\
\hline F9 & $0.4564 \pm 0.09$ & $0.5467 \pm 0.07$ & $27.89 \pm 0.84$ & $14.57 \pm 0.68$ & $1.03 \pm 0.04$ \\
\hline
\end{tabular}

Data expressed are average of triplicate $(n=3 \pm S D)$

\begin{tabular}{|c|c|c|c|c|}
\hline \multirow[b]{2}{*}{$\begin{array}{l}\text { Formulation } \\
\text { Batches }\end{array}$} & \multicolumn{4}{|c|}{ Parameters } \\
\hline & $\begin{array}{l}\text { Weight variation(mg) } \\
\qquad( \pm \mathrm{SD})\end{array}$ & $\begin{array}{l}\text { Wetting time(sec.) } \\
\qquad( \pm \text { SD) }\end{array}$ & $\begin{array}{c}\text { Water absorption ratio } \\
\text { (\%) } \\
( \pm \text { SD) }\end{array}$ & $\begin{array}{c}\text { Disintegration Time (sec.) } \\
( \pm \text { SD) }\end{array}$ \\
\hline F1 & $100.87 \pm 0.55$ & $93.67 \pm 2.59$ & $78.49 \pm 1.68$ & $70.66 \pm 3.78$ \\
\hline F2 & $99.29 \pm 0.75$ & $83.34 \pm 1.52$ & $53.39 \pm 0.76$ & $69 \pm 2$ \\
\hline F3 & $98.75 \pm 1.0$ & $82.34 \pm 1.52$ & $77.7 \pm 1.68$ & $67.67 \pm 4.04$ \\
\hline $\mathrm{F} 4$ & $102.57 \pm 0.86$ & $76.66 \pm 1.52$ & $68.48 \pm 1.31$ & $73 \pm 5.2$ \\
\hline F5 & $101.49 \pm 1.57$ & $68 \pm 0.57$ & $69.33 \pm 2.51$ & $68.34 \pm 3.05$ \\
\hline F6 & $98.44 \pm 0.77$ & $62.67 \pm 0.57$ & $82.52 \pm 1.76$ & $61.67 \pm 2.51$ \\
\hline F7 & $101.30 \pm 0.94$ & $74.66 \pm 1.52$ & $67.44 \pm 1.53$ & $73.67 \pm 2.08$ \\
\hline F8 & $98.82 \pm 0.99$ & $72.66 \pm 2.08$ & $68.18 \pm 0.70$ & $71 \pm 3$ \\
\hline F9 & $97.56 \pm 0.56$ & $67.67 \pm 1.52$ & $58.15 \pm 1.66$ & $68.35 \pm 2.43$ \\
\hline
\end{tabular}

Data expressed are average of triplicate $(n=3 \pm S D)$

\section{Thickness}

Thickness of Tablet formulations was found to be ranging from $3.5 \mathrm{~mm}$ to $3.73 \mathrm{~mm}$. Variation of thickness in Tablet formulations (F1 to F9) was found within the acceptable limits.

\section{Hardness}

Hardness of Tablet formulations was found to be ranging from $2.4 \mathrm{Kg} / \mathrm{cm}^{2}$ to $3.4 \mathrm{Kg} / \mathrm{cm}^{2}$. Results obtained are within acceptable limit and indicated good mechanical strength.

\section{Drug content uniformity study}

Percent drug content of Apremilast was found in between $98.31 \%-102.53 \%$ and found to be satisfactorily.

\section{Friability}

Friability of Tablet formulations was found to be ranging from $0.67 \%$ to $0.91 \%$ which is within the acceptable limits. Friability values below 1\% indicate a good tablet mechanical strength.

\section{Weight variation}

Weight variation of tablet formulation was found to be in $97.56 \mathrm{mg}$ to $102.57 \mathrm{mg}$ which is within acceptable limit and up to $7.5 \%$ standard deviation is allowed, according to the I.P.

\section{Wetting time}

Wetting time of all formulation (F1-F9) was found satisfactorily and in between 62 to $93 \mathrm{sec}$. From F1 to F9 formulations, F6 formulation required less wetting time. 


\begin{tabular}{|c|c|c|c|c|}
\hline \multirow{2}{*}{ Formulation Batches } & \multicolumn{4}{|c|}{ Parameters } \\
\cline { 2 - 5 } & $\begin{array}{c}\text { Thicknes (mm) } \\
( \pm \text { SD) }\end{array}$ & $\begin{array}{c}\left.\text { Hardness (Kg/cm }{ }^{2}\right) \\
( \pm \text { SD) }\end{array}$ & $\begin{array}{c}\text { Drug content (\%) } \\
( \pm \text { SD) }\end{array}$ & $\begin{array}{c}\text { Friability } \\
(\%)\end{array}$ \\
\hline F1 & $3.5 \pm 0.30$ & $3.1 \pm 0.57$ & $99.40 \pm 1.78$ & $0.76 \pm 0.02$ \\
\hline F2 & $3.7 \pm 0.05$ & $2.4 \pm 0.28$ & $98.77 \pm 2.61$ & $0.68 \pm 0.11$ \\
\hline F3 & $3.7 \pm 0.23$ & $2.7 \pm 0.28$ & $101.09 \pm 1.43$ & $0.67 \pm 0.12$ \\
\hline F4 & $3.6 \pm 0.05$ & $3 \pm 0.5$ & $102.53 \pm 1.79$ & $0.73 \pm 0.12$ \\
\hline F5 & $3.5 \pm 0.1$ & $2.5 \pm 0.5$ & $98.87 \pm 2.58$ & $0.91 \pm 0.05$ \\
\hline F6 & $3.7 \pm 0.15$ & $2.4 \pm 0.28$ & $101.27 \pm 2.41$ & $0.77 \pm 0.01$ \\
\hline F7 & $3.6 \pm 0.05$ & $3.4 \pm 0.28$ & $99.72 \pm 3.37$ & $0.74 \pm 0.03$ \\
\hline F8 & $3.73 \pm 0.15$ & $3.1 \pm 0.28$ & $98.31 \pm 3.27$ & $0.67 \pm 0.01$ \\
\hline F9 & $3.5 \pm 0.4$ & $2.83 \pm 0.57$ & $98.67 \pm 0.73$ & $0.75 \pm 0.02$ \\
\hline
\end{tabular}

Data expressed are average of triplicate $(n=3 \pm S D)$

\begin{tabular}{|c|c|c|c|c|c|c|c|c|}
\hline \multirow{2}{*}{$\begin{array}{c}\text { Formulation } \\
\text { Code }\end{array}$} & \multicolumn{8}{|c|}{ Time (Min) } \\
\hline & 1 & 3 & 5 & 7 & 9 & 11 & 13 & 15 \\
\hline F1 \%CDR & $24.06 \pm 1.89$ & $38 \pm 0.98$ & $56.07 \pm 0.56$ & $74.19 \pm 0.65$ & $80.45 \pm 1.64$ & $83.76 \pm 0.51$ & $85.78 \pm 1.89$ & $87 \pm 2.76$ \\
\hline F2 \% CDR & $28.23 \pm 0.60$ & $39.37 \pm 1.93$ & $51.45 \pm 0.68$ & $63.54 \pm 1.23$ & $74.26 \pm 2.67$ & $82.21 \pm 1.34$ & $86.93 \pm 0.54$ & $89.39 \pm 1.89$ \\
\hline F3 \%CDR & $31.01 \pm 0.04$ & $43.07 \pm 0.56$ & $54.23 \pm 2.67$ & $60.31 \pm 1.52$ & $73.34 \pm 1.87$ & $84.53 \pm 0.23$ & $88.32 \pm 0.50$ & $92.59 \pm 0.35$ \\
\hline F4 \%CDR & $29.62 \pm \pm 0.65$ & $42.15 \pm 1.32$ & $59.78 \pm 0.43$ & $72.81 \pm 0.58$ & $83.54 \pm 1.54$ & $85.48 \pm 1.78$ & $88.32 \pm 2.87$ & $90.77 \pm 1.69$ \\
\hline F5 \%CDR & $33.32 \pm 0.34$ & $46.48 \pm 0.45$ & $54 \pm 1.63$ & $77.11 \pm 1.87$ & $90.77 \pm 2.45$ & $92.59 \pm 0.43$ & $94.87 \pm 0.35$ & $96.85 \pm 0.41$ \\
\hline F6 \%CDR & $30.54 \pm 0.67$ & $43.54 \pm 0.34$ & $62.5 \pm 1.34$ & $74.2 \pm 0.23$ & $85.39 \pm 0.78$ & $87.34 \pm 1.73$ & $92.56 \pm 1.61$ & $98.7 \pm 0.48$ \\
\hline F7 \%CDR & $26.38 \pm 1.23$ & $42.61 \pm 2.67$ & $53.3 \pm 1.34$ & $61.23 \pm 0.41$ & $70.55 \pm 0.42$ & $79.89 \pm 0.60$ & $85.53 \pm 0.79$ & $88.4 \pm 1.20$ \\
\hline F8 \%CDR & $29.92 \pm 1.45$ & $42.68 \pm 2.67$ & $57.93 \pm 0.44$ & $74.66 \pm 2.89$ & $81.64 \pm 1.98$ & $85.67 \pm 0.32$ & $89.56 \pm 1.47$ & $94.67 \pm 1.65$ \\
\hline F9 \%CDR & $30.54 \pm 0.40$ & $44.46 \pm 0.57$ & $56.08 \pm 1.56$ & $63.09 \pm 1.66$ & $72.42 \pm 0.78$ & $82.66 \pm 0.98$ & $88.67 \pm 0.54$ & $95.88 \pm 0.65$ \\
\hline
\end{tabular}

$\%$ CDR is Percent Cumulative Drug Release.

\section{Water absorption ratio}

Water absorption ratio was found in ranging from 53.39 $\%$ to $82.52 \%$ and the results indicated that formulation F6 had higher water absorption ratio when compared to other formulations.

\section{Disintegration time}

According to European Pharmacopoeia, Orodispersible Tablets should disintegrate within three minute. The disintegration time for formulation F1-F9 was found to be in the range of 61 to $73 \mathrm{sec}$ and from all formulations, F6 formulation required less disintegration time. ${ }^{21}$

\section{In-vitro drug Release Study of Apremilast Tablet}

Percent drug release data expressed in Table 9 and Figure 1 Indicate in-vitro release study was shown 98.7\% release of apremilast through F6 formulation in $15 \mathrm{~min}$ and up to $5 \%$ standard deviation is allowed. Formulation F6 showed less disintegration time and percent cumulative drug release $98.7 \%$ so it was declared as an

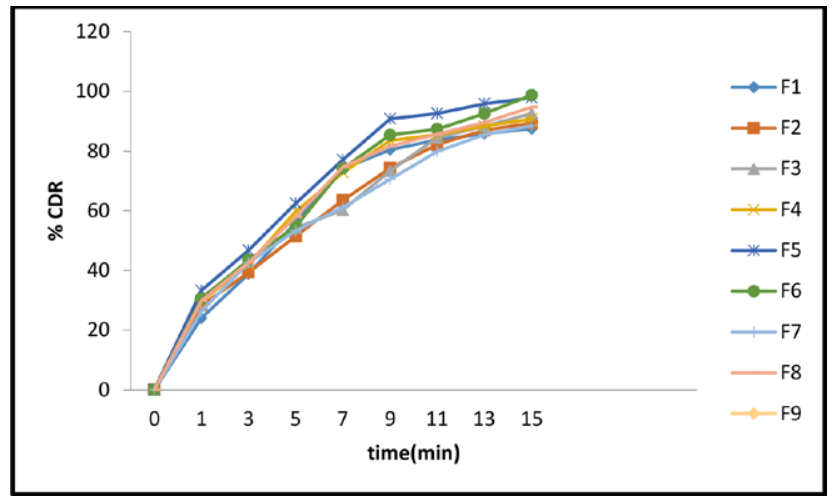

Figure 1: Dissolution profile of Orodispersible tablets of Apremilast. \% CDR is Percent Cumulative Drug Release of F1 to F9 formulations within $15 \mathrm{~min}$.

optimized formulation and was subjected for further evaluation (Table 10) and stability studies. ${ }^{22}$

\section{Stability Study}

The accelerated stability study was carried out on optimized formulation F6. The tablets were wrapped 


\section{Table 10: Evaluation parameters of $\mathrm{f} 6$ optimized} batch.

\begin{tabular}{|c|c|c|}
\hline Sr. No. & Parameters & Results \\
\hline 1 & Weight variation $(\mathrm{mg})$ & $98.30 \pm 1.90$ \\
\hline 2 & Thickness $(\mathrm{mm})$ & $3.8 \pm 0.05$ \\
\hline 3 & Hardness $\left(\mathrm{kg} / \mathrm{cm}^{2}\right)$ & $2.17 \pm 0.28$ \\
\hline 4 & Friability $(\%)$ & $0.72 \pm 0.05$ \\
\hline 5 & Wetting time (sec) & $67.66 \pm 3.51$ \\
\hline 6 & Disintegration time (sec) & $61.66 \pm 2.51$ \\
\hline 7 & Uniformity of content (\%) & $98.46 \pm 1$ \\
\hline 8 & Water absorption ratio (\%) & $58.28 \pm 6.26$ \\
\hline
\end{tabular}

Data expressed are average of triplicate $(n=3 \pm S D)$

\begin{tabular}{|c|c|c|}
\hline \multicolumn{3}{|c|}{$\begin{array}{c}\text { Table 11: Parameters studied of [f6] formulation } \\
\text { before and after stability study. }\end{array}$} \\
\hline Parameters & $\begin{array}{c}\text { Before stability } \\
\text { study }\end{array}$ & $\begin{array}{c}\text { After stability } \\
\text { study }\end{array}$ \\
\hline Colour & White & White \\
\hline Thickness (mm) & $3.87 \pm 0.05$ & $3.67 \pm 0.20$ \\
\hline Hardness (kg/cm $\left.{ }^{2}\right)$ & $2.17 \pm 0.28$ & $2.34 \pm 0.28$ \\
\hline Content uniformity (\%) & $98.46 \pm 1$ & $97.66 \pm 1.15$ \\
\hline Weight variation(mg) & $99.73 \pm 1.90$ & $99.73 \pm 1.90$ \\
\hline Friability (\%) & $0.72 \pm 0.05$ & $0.74 \pm 0.5$ \\
\hline Disintegration time (sec.) & $61.66 \pm 2.51$ & $62.33 \pm 2.08$ \\
\hline Wetting time (sec.) & $67.66 \pm 2$ & $66.67 \pm 1.52$ \\
\hline Water absorption ratio (\%) & $58.27 \pm 6.26$ & $57.54 \pm 6.21$ \\
\hline Dissolution study (\%) & $98.7 \pm 0.48$ & $98.2 \pm 0.64$ \\
\hline
\end{tabular}

Data expressed are average of triplicate $(n=3 \pm S D)$

in aluminium foil and stored at $40 \pm 2{ }^{\circ} \mathrm{C}$ and $75 \pm 5 \%$ $\mathrm{RH}$ for a three months. After three months samples were withdrawn and tested for physical parameters, thickness, hardness, percent friability, content uniformity, disintegration time, wetting time, Water absorption ratio (\%) and in-vitro drug release studies. ${ }^{23}$ Table 11 showed that there was no considerable change in thickness, hardness, percent friability, content uniformity, disintegration time, wetting time, Water absorption ratio ( $\%$ ) and dissolution data of formulation F6 before and after accelerated stability study. Also formulation F6 showed white color after stability studies. Hence, Orodispersible tablet (F6) prepared was found to be stable. ${ }^{24,25}$

\section{CONCLUSION}

The major problem of BCS-Class 4 Apremilast drug is low solubility and low permeability. Results revealed that it is possible to enhance the dissolution rate and bioavailability by preparing inclusion complex of apremilast with $\beta$-cyclodextrin and direct compression technique using super disintegrant Croscarmellose sodium. The overall results indicate that among all formulations (F1 to F9) studied, Formulation F6 which contains $5 \%$ Croscarmellose sodium with 1:2 ratio of apremilast: $\beta$-cyclodextrin which shows less disintegration time and percent cumulative drug release 98.7\%,was better and hence F6 formulation satisfies all the criteria as a orodispersible tablet and achieve better patient compliance in Cost-effective manner as compared with conventional treatment of psoriasis.

\section{ACKNOWLEDGEMENT}

Authors are thankful to Glenmark Pharmaceuticals Ltd., (Pune, India) for providing Apremilast drug as a gift sample. Also, authors are very much grateful to the Principal, R.G. Sapkal College of Pharmacy, Nashik for providing necessary facilities to carry out the research work.

\section{CONFLICT OF INTEREST}

The authors declare no conflicts of interest.

\section{ABBREVIATIONS}

APM: Apremilast; CD: Cyclodextrin; PM: Physical Mixture; Min: Minutes; Hrs: Hours; Sec: Seconds; mg: Milligram; ml: Milliliter; $\mu \mathrm{g}$ : Micro gram; gm: Grams; m: Meter; cm: Centimeters; RH: Relative Humidity; rpm: Revolutions per minute; UV: Ultra-violet; w/w: weight by weight; $\mathbf{n m : ~ N a n o m e t e r ; ~ S D : ~ S t a n d a r d ~}$ Deviation.

\section{REFERENCES}

1. Habib W, Khankari R, Hontz J. Fast dissolving drug delivery systems-Critical Reviews in Therapeutics. Drug Carrier Systems. 2000;17(1):61-72.

2. Dey P, Maiti S. Orodispersible tablets: A new trend in drug delivery. Journal of Natural Science, Biology and Medicine. 2010;1(1):2-5.

3. Winterfield LS, Menter A, Gordon K, Gottlieb A. Psoriasis treatment: Current and emerging directed therapies. Annals of the Rheumatic Diseases. 2005;64(suppl 2):87-90.

4. Chadar L, Shukla V, Jain SK. Formulation and Assessment of Mouth Dissolving Tablets of Repaglinide-ß-Cyclodextrin Complex. UK Journal of Pharmaceutical and Biosciences. 2014;2(2):8-15.

5. Loftsson T, Jarho P, Masson M, Jarvinen T. Cyclodextrins in drug delivery. Expert Opinion on Drug Delivery. 2005;2(2):335-51.

6. Ghosh A, Biswas S, Ghosh T. Preparation and evaluation of silymarin $\beta$-cyclodextrin molecular inclusion complexes. Journal of Young Pharmacists. 2011;3(3):205-10.

7. Gulsun T, Ozturk N, Kaynak MS, Vural I, Sahin S. Preparation and evaluation of furosemide containing orally disintegrating tablets by direct compression. Die Pharmazie an International Journal of Pharmaceutical Sciences. 2017;72(7):389-94.

8. Awasthi $\mathrm{R}$, et al. Formulation and characterization of oral rapid disintegrating tablets of levocetirizine. Polymers in Medicine. 2018;48(1):31-40.

9. Obaidat A, Obaidat R. Development and evaluation of fast-dissolving tablets of meloxicam- $\beta$-cyclodextrin complex prepared by direct compression. Acta Pharmaceutica. 2011;61(1):83-91. 
10. Ammar HO, Salama HA, Ghorab M, Mahmoud AA. Implication of inclusion complexation of glimepiride in cyclodextrin-polymer systems on its dissolution, stability and therapeutic efficacy. International Journal of Pharmaceutics. 2006;320(1-2):53-7.

11. Rasheed A, et al. Cyclodextrins as drug carrier molecule: A review. Scientia Pharmaceutica. 2008;76(4):567-98.

12. Borghetti GS, Lula IS, Sinisterra RD, Bassani VL. Quercetin/ $\beta$-cyclodextrin solid complexes prepared in aqueous solution followed by spray-drying or by physical mixture. Aaps Pharmscitech. 2009;10(1):235-42.

13. Shimpi S, Chauhan B, Shimpi P. Cyclodextrins: Application in different routes of drug administration. Acta Pharmaceutica. 2005;55(2):139-56.

14. Sunada $\mathrm{H}, \mathrm{Bi}$ Y. Preparation, evaluation and optimization of rapidly disintegrating tablets. Powder Technology. 2002;122(2-3):188-98.

15. Ghosh T, Ghosh A, Prasad D. A review on new generation or dispersible tablets and its future prospective. International Journal of Pharmacy and Pharmaceutical Sciences. 2011;3(1):1-7.

16. Baboota S, Dhaliwal M, Kohli K. Physicochemical characterization in vitro dissolution behaviour and pharmacodynamic studies of rofecoxibcyclodextrin inclusion compounds: A technical note. AAPS Pharm Sci Tech. 2005;6(1):83-90.

17. Zhao N, Augsburger LL. Functionality comparison of three classes of superdisintegrants in promoting aspirin tablet disintegration and dissolution. AAPS Pharm Sci Tech. 2005;6(4):634-40.

18. Chavan BA, Mali KK, Dias RJ. Formulation and evaluation of melt-inmouth tablets of domperidone containing multicomponent inclusion complex. International Journal of Pharmacy and Pharmaceutical Sciences. 2012;4(1):71-5.

19. Omari MM, Zughul MB, Davies JE, Badwan AA. Astemizole/cyclodextrin inclusion complexes: Phase solubility, physicochemical characterization and molecular modeling studies. Journal of Solution Chemistry. 2008;37(6):875-93.

20. Mehramizi A, Asgari ME, et al. Influence of $\beta$-cyclodextrin complexation on lovastatin release from osmotic pump tablets. Journal of Pharmaceutical Sciences. 2007;15(2):71-8.

21. Leuner C, Dressman J. Improving drug solubility for oral delivery using solid dispersions. European Journal of Pharmaceutics and Biopharmaceutics. 2000;50(1):47-60.

22. Wu CY, Benet LZ. Predicting drug disposition via application of BCS: transport/ absorption/elimination interplay and development of a biopharmaceutics drug disposition classification system. Pharmaceutical Research. 2005;22(1):11-23.

23. Chandrasekhar R, Hassan Z, AlHusban F, Smith AM, Mohammed AR. The role of formulation excipients in the development of lyophilised fast-disintegrating tablets. European Journal of Pharmaceutics and Biopharmaceutics. 2009;72(1):119-29.

24. Kuno $\mathrm{Y}, \mathrm{Kojima} \mathrm{M}$, Ando S, Nakagami H. Evaluation of rapidly disintegrating tablets manufactured by phase transition of sugar alcohols. Journal of Controlled Release. 2005;105(1-2):16-22.

25. Abdelbary G, Eouani C, Prinderre P, Joachim J, Reynier JP, Piccerelle PH. Determination of the in vitro disintegration profile of rapidly disintegrating tablets and correlation with oral disintegration. International Journal of Pharmaceutics. 2005;292(1-2):29-41.

\section{PICTORIAL ABSTRACT}

Apremilast- $\beta$-Cyclodextrin Inclusion complex by Physical Blending Method

Inclusion efficiency of Apremilast : $\beta$-Cyclodextrin (1:1,1:2,1:3) study shows 1:2 ratio complex is highest

Orodispersible tablets of Apremilast (F1 to F9) by direct compression technique using different concentrations of superdisintegrant Crosscarmellose sodium
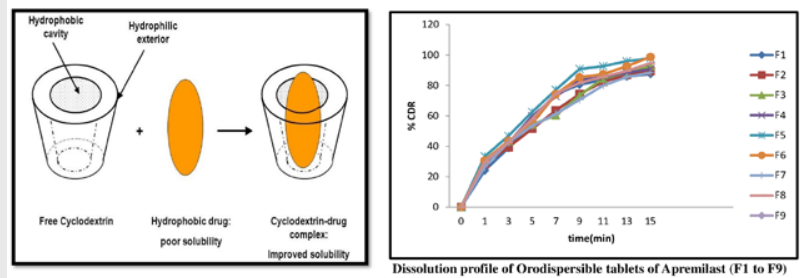

\section{About Authors}

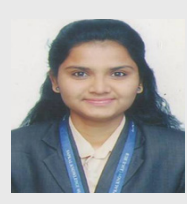

Miss. Darshana P. Panhale, is a postgraduate (M.Pharm; Pharmaceutical Quality Assurance) at R.G. Sapkal College of Pharmacy, Anjaneri, Nashik, Maharashtra, India. She is a post-graduate diploma student (Intellectual Property Rights and Drug Regulatory Affairs) at NDMVP's College of Pharmacy, Nashik, Maharashtra, India.

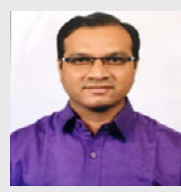

Dr. Rishikesh S. Bachhav, is a Professor and Head of the Department of Pharmacology, R.G. Sapkal College of Pharmacy, Anjaneri, Nashik, Maharashtra, India.

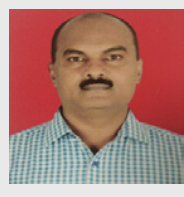

Prof. Sheetal B. Gondkar, post-graduate from NDMVP's, College of Pharmacy, Nashik. He has 25 years work experience in academics and guided 70 M.Pharmacy students. He is a Associate professor (Department Of Pharmaceutics) at R.G. Sapkal College of Pharmacy, Anjaneri, Nashik, Maharashtra, India.

\section{SUMMARY}

Apremilast was successfully formulated in orodispersible tablet by inclusion complexation with $\beta$-cyclodextrin. F6 formulation was selected as optimized formulation based on disintegration time and percent cumulative drug release. Acceptable stability profile was observed after subjecting the optimized F6 formulation to various conditions of temperature and humidity. Hence, it can be concluded that Apremilast orodispersible tablets prepared with $\beta$-cyclodextrin and cross Croscarmellose can be a choice for oral antipsoriasis treatment in a cost-effective manner with better patient compliance.

Cite this article: Panhale DP, Bachhav RS, Gondkar SB. Formulation and Evaluation of Orodispersible Tablets of Apremilast by Inclusion Complexation using $\beta$-Cyclodextrin. Indian J of Pharmaceutical Education and Research. $2021 ; 55(1 \mathrm{~s}):$ s $112-\mathrm{s} 121$. 